УДК 663.11+663.43+557.15

\title{
НАКОПЛЕНИЕ АМИЛОЛИТИЧЕСКИХ ФЕРМЕНТОВ В ЗЕРНЕ ПШЕНИЦЫ В ПРОЦЕССЕ ПРОРАЩИВАНИЯ ПРИ ПОЛУЧЕНИИ ПШЕНИЧНОГО \\ СоЛОДА
}

() М.Ф. Ростовская ${ }^{* 1}$, А.Н. Извекова ${ }^{1}$, А.Г. Кльков ${ }^{2}$

${ }^{1}$ Дальневосточный федеральный университет, Школа биомедицины, Суханова, 8, Владивосток, 690950 (Россия), e-mail: rost-mf@mail.ru

${ }^{2}$ Приморский научно-исследовательский институт сельского хозяйства, Воложенина, 30, п. Тимирязевский, Уссурийский район, 692539 (Россия), e-mail: fe.smc_ef@mail.ru

Определено содержание белка, крахмала, амилолитических ферментов в зерне двух сортов яровой пшеницы (Triticum aestivum L), выращиваемых в Приморском крае. Исследовано накопление амилолитических ферментов в процессе проращивания пшеницы с различным уровнем белковых веществ в зерне, а также изучено влияние режима проращивания на образование амилолитических ферментов с целью оптимизации процесса солодоращения зерна при получении пшеничного солода.

Ключевые слова: амилолитические ферменты, диастатическая сила, проращивание, пшеница, содержание белка, солод.

\section{Введение}

Пшеница - важнейшая продовольственная культура мира. Основными производителями являются Канада, США, Китай, Индия и Россия [1]. В России в 2011 г. площадь посева под пшеницей составила 25,5 млн га, валовой сбор - 56,2 млн тонн [2].

Основное направление выращивания пшеницы (Triticum) - производство зерна для хлебопекарной, кондитерской, макаронной, крупяной промышленности [3] и производства фуража [4]. Но пшеницу также используют и в пивоварении. Ее применяют как в виде зерна, добавляя в засыпь до 40\%, так и в виде пшеничного солода (до 80\%) при получении так называемого белого пива [5]. Кроме того, пшеницу и пшеничный солод используют в качестве добавки к ячменному солоду в пивной индустрии для увеличения выхода экстракта и получения более стабильной пены [6]. Требования к зерну пшеницы, предназначенной для хлебопечения и получения пивоваренного солода, различны. Если для мукомольной промышленности необходимо высокое содержание клейковины, т.е. высокий уровень белка в зерне [7], то для солодоращения больше подходят сорта с низким содержанием белка [8]. Исследования по созданию специальных сортов пшеницы для пивоваренной промышленности не проводятся. Сорта, отвечающие требованиям для солодоращения, подбирают среди уже возделываемых сортов пшеницы [8].

Ростовская Марина Феликсовна - доцент кафедры продуктов питания из растительного сырья, кандидат химичеких наук, тел.: (423)240-65-69,

e-mail: rost-mf@mail.ru

Извекова Анастасия Николаевна - студентка Кльюков Алексей Григорьевич - заведующий лабораторией селекции зерновых и крупяных культур, доцент, кандидат сельско-хозяйственных наук, тел.: (423) 239-27-19, e-mail: fe.smc_rf@mail.ru
Солод получают контролируемым проращиванием зерна. Один из важнейших показателей пивоваренного солода - экстрактивность - зависит от содержания крахмала в зерне. Экстрактивность обеспечивается рядом сбраживаемых углеводов, которые образуются при гидролизе крахмала во время процессов солодоращения и затирания $[9,10]$. Кроме

\footnotetext{
* Автор, с которым следует вести переписку.
} 
общего содержания крахмала в зерне пшеницы, на экстрактивность солода влияет структура крахмала [11]. На качество пшеничного солода также влияет уровень белка в зерне [8]. Высокий уровень белка приводит к образованию белково-крахмального комплекса, что ограничивает гидратацию эндосперма во время проращивания и замедляет модификацию эндосперма и образование ферментов [10].

Таким образом, считается, что для получения качественного пивоваренного пшеничного солода пригодны сорта пшеницы с низким содержанием белка и высоким содержанием крахмала [8].

Для достижения более полного расщепления крахмала необходимо, чтобы в зерне во время проращивания образовалось достаточное количество амилолитических ферментов. Гидролиз крахмала в зерне осуществляется в основном четырьмя ферментами: $\alpha$-амилазой, $\beta$-амилазой, предельной декстриназой и $\alpha$-глюкозидазой. Активность этих четырех амилолитических ферментов в совокупности называется диастатической силой (ДС). Диастатическая сила позволяет оценить способность солода превращать крахмал в сбраживаемые дрожжами сахара $[9,12]$. Уровень ДС в хорошем пшеничном солоде должен быть достаточно высок - 300-400 ед. Виндиш - Кольбаха и выше [8, 10].

На образование амилолитических ферментов во время проращивания зерна влияет ряд факторов. Ранее считалось, что непроросшее зерно с более высоким содержанием белка будет давать солод с более высоким уровнем амилолитических ферментов [13], но имеются данные, которые противоречат этому утверждению $[14,15]$. На уровень амилолитической активности также влияет окружающая среда во время созревания зерна [16]. В литературе имеются сведения, что на образование амилолитических ферментов можно влиять, меняя режим солодоращения $[8,17]$.

Цель настоящей работы - изучение накопления амилолитических ферментов в процессе проращивания пшеницы с различным уровнем белка в зерне, а также исследование влияния режима солодоращения на образование амилолитических ферментов.

\section{Экспериментальная часть}

Для исследования использовали два районированных сорта яровой мягкой пшеницы (Triticum aestivum L ) дальневосточной селекции урожая 2010 г. - Приморская 39, Приморская 40, отличающихся уровнем содержания белка. Образцы выращивались в одном и том же месте и одних и тех же погодных условиях, но имели отличие в генотипе [18]. Все сорта пшеницы получены в ПримНИИСХ, п. Тимирязевский.

Анализ зерна проводили по стандартным методикам, определяя массу 1000 зерен (ГОСТ 10842-89), энергию и способность прорастания (ГОСТ 10968-88), содержание влаги (ГОСТ 13586.5-93). Массовую долю белка измеряли по методу Кьельдаля (ГОСТ 10846-76), массовую долю крахмала - поляриметрическим методом, определяя количество оптически активных сахаров, образовавшихся после гидролиза крахмала (ГОСТ 10845-76), амилолитическую активность (диастатическую силу) измеряли методом Виндиш Кольбаха, основанном на титриметрическом определении количества нерасщепленного крахмала после обработки крахмального раствора амилолитическими ферментами, содержащимися в солодовой вытяжке. ДС принято выражать в единицах Виндиш - Кольбаха, что соответствует количеству грамм мальтозы, образовавшейся из крахмала под действием 100 г солода в течение 30 мин при $20^{\circ} \mathrm{C}$ (European Brewing Convention Analytic, method 4.12, 1998).

Зерно обоих сортов подвергали проращиванию в одинаковых условиях при убывающих температуpax от 19 до $15^{\circ} \mathrm{C}$. Проращивание зерна проводили в хладотермостате XT-3/70-2. Общее время солодоращения составило 91 ч. После этого часть солода сушили в сушильном шкафу Binder FD-2, получая сухой солод, а оставшуюся часть продолжали проращивать до общего времени проращивания 167 ч. В процессе солодоращения ежедневно отбирали пробы зерна и измеряли содержание влаги, используя влагомер «Элвиз 2», а также диастатическую силу методом Виндиш - Кольбаха.

Зерно пшеницы сорта Приморская 40 также подвергли проращиванию при возрастающих температурах в интервале от 11 до $15^{\circ} \mathrm{C}$. Общее время солодоращения составило 122 ч. После этого часть солода сушили в сушильном шкафу Binder FD-2, получая сухой солод, а оставшуюся часть продолжали проращивать до общего времени проращивания 196 ч. В процессе солодоращения ежедневно отбирали пробы зерна и измеряли содержание влаги, используя влагомер «Элвиз 2», также диастатическую силу солода методом Виндиш - Кольбаха.

Экстрактивность сухого солода определяли по плотности лабораторного сусла (ГОСТ 12601-77).

Статистическую обработку вели с использованием пакета стандартных программ. 


\section{Обсуждение результатов}

Показатели зерна представлены в таблице 1. О степени пригодности зерна к проращиванию судят по показателям энергии и способности прорастания. Зерно, предназначенное для солодоращения, должно иметь высокую способность прорастания - выше 95\%. Также большое значение имеет разница между энергией прорастания и способностью прорастания. Нежелательна разница свыше $2 \%$, поскольку в процессе прорастания зерна параллельно с активацией имеющихся в зерне ферментов происходит образование новых. Большая разница приводит к неравномерному растворению веществ эндосперма зерна и не позволяет полностью осуществить растворение зерна [8]. Оба сорта показали высокую энергию и способность прорастания.

Считается, что оптимальный уровень белка в пшенице, предназначенной для солодоращения, не должен превышать $12 \%$ [8], но в недавних исследованиях показано, что хороший пшеничный солод можно получить из пшеницы с содержанием белка 16\% [14]. Из таблицы 1 видно, что разница в уровне белка исследуемых сортов составляет около 2\%. Уровень крахмала в зерне обоих сортов примерно одинаковый, несмотря на разницу в содержании белка. В литературе по этому поводу содержатся противоречивые сведения. В некоторых работах выявлена обратно пропорциональная зависимость между содержанием белка и содержанием крахмала в зерне пшеницы [14], в других исследованиях такой зависимости не наблюдается - сорта с различным уровнем белка могут показывать сходный уровень крахмала [10]. Диастатическая сила непроросшего зерна небольшая. Основной вклад в величину ДС вносит $\beta$-амилаза, которая в непроросшем зерне находится в двух формах - свободной и связанной, причем последняя значительно преобладает. В непроросшем зерне $\alpha$-амилаза и предельная декстриназа практически не определяются [8, 10].

Амилолитические ферменты образуются или переходят в активную форму при проращивании зерна. Образование достаточного количества ферментов в проращиваемом зерне является одной из важнейших задач солодоращения [9]. Мы исследовали динамику накопления амилолитических ферментов на примере двух сортов пшеницы с различным содержанием белка в процессе проращивания в режиме убывающих температур. Данные по изменению диастатической силы в процессе солодоращения представлены в таблице 2.

Максимум образования амилолитических ферментов у сорта Приморская 40 зафиксирован в конце 4-х суток проращивания, а у сорта Приморская 39 - на сутки позднее, при дальнейшем проращивании наблюдалось уменьшение активности амилолитических ферментов. То, что максимум образования амилолитических ферментов может приходиться на разное время проращивания в зависимости от сортовых особенностей пшеницы, таких как содержание крахмала и белка, было ранее показано на примере китайских сортов пшеницы $[10,18]$.

Таким образом, чтобы получить солод с максимальным содержанием амилолитических ферментов, пшеницу сорта Приморская 40 достаточно проращивать 4 суток, а пшеницу сорта Приморская 39 - 5 суток.

В нашем случае пшеница сорта Приморская 40, имеющая более высокий уровень белка в зерне, показала меньшее значение максимальной диастатической силы при проращивании, что согласуется с данными некоторых авторов [14, 15, 19]. В работе [15] показано, что в зерне с более низким уровнем азотистых веществ происходит более быстрое развитие $\alpha$ - и $\beta$-амилаз.

Разница между сортами в момент наибольшего значения ДС в каждом образце составляла более 150 ед. Виндиш - Кольбаха. Возможно, на такую большую разницу оказала и величина влажности зерна. Несмотря на более частое орошение, пшеница сорта Приморская 40 набирала влагу медленнее, чем Приморская 39. У сорта Приморская 40 более крупное зерно (табл. 1), при этом оба сорта обладают сходной водочувствительностью [20].

Таблица 1. Показатели зерна пшеницы

\begin{tabular}{l|c|c}
\hline \multicolumn{1}{c|}{ Показатель } & Приморская 39 & Приморская 40 \\
\hline Масса 1000 зерен, г & $32,16 \pm 0,12$ & $41,38 \pm 0,07$ \\
Энергия прорастания, \% & $98,2 \pm 0,4$ & $98,7 \pm 0,1$ \\
Способность прорастания, \% & $98,6 \pm 0,2$ & $99,0 \pm 0,1$ \\
Содержание влаги, \% & $8,3 \pm 0,05$ & $10,3 \pm 0,07$ \\
Массовая доля белка, \%, СB ${ }^{1}$ & $13,16 \pm 0,47$ & $15,31 \pm 0,31$ \\
Массовая доля крахмала, \%, СВ & $64,11 \pm 0,38$ & $63,62 \pm 0,25$ \\
Диастатическая сила $\mathrm{WK}^{2}, \mathrm{CB}$ & $62,8 \pm 2,2$ & $55,1 \pm 3,3$ \\
\hline
\end{tabular}

Примечание: ${ }^{\mathrm{C}} \mathrm{CB}$ - сухое вещество; ${ }^{2} \mathrm{WK}$ - единицы Виндиш - Кольбаха. 
Таблица 2. Изменение диастатической силы пшеницы в процессе проращивания в режиме убывающих температур

\begin{tabular}{c|c|c|c|c|c|c|c}
\hline \multicolumn{4}{c|}{ Приморская 39 } & \multicolumn{3}{c}{ Приморская 40 } \\
\hline $\begin{array}{c}\text { Время от } \\
\text { начала со- } \\
\text { лодораще- } \\
\text { ния, ч }\end{array}$ & $\begin{array}{c}\text { Содержание } \\
\text { влаги } \\
\text { в зерне, \% }\end{array}$ & $\begin{array}{c}\text { Диастати- } \\
\text { ческая } \\
\text { сила, }{ }^{\circ} \mathrm{WK}\end{array}$ & $\begin{array}{c}\text { ДС, CB, } \\
{ }^{\circ} \mathrm{WK}\end{array}$ & $\begin{array}{c}\text { Время от } \\
\text { начала со- } \\
\text { лодораще- } \\
\text { ния, ч }\end{array}$ & $\begin{array}{c}\text { Содержание } \\
\text { влаги } \\
\text { в зерне, \% }\end{array}$ & $\begin{array}{c}\text { Диаста- } \\
\text { тическая } \\
\text { сила, }{ }^{\circ} \mathrm{WK}\end{array}$ & $\begin{array}{c}\text { ДС, CВ, } \\
{ }^{\circ} \mathrm{WK}\end{array}$ \\
\hline 0 & $8,3 \pm 0,05$ & $56,6 \pm 1,7$ & $62,8 \pm 2,2$ & 0 & $10,3 \pm 0,07$ & $49,4 \pm 2,1$ & $55,1 \pm 3,3$ \\
3 & $28,6 \pm 0,09$ & $67,7 \pm 0,9$ & $94,8 \pm 2,1$ & 3 & $26,1 \pm 0,06$ & $82,3 \pm 1,9$ & $111,4 \pm 3,5$ \\
23 & $39,0 \pm 0,04$ & $147,7 \pm 2,0$ & $241,9 \pm 3,8$ & 25 & $38,2 \pm 0,07$ & $147,4 \pm 2,4$ & $238,7 \pm 3,9$ \\
47 & $44,3 \pm 0,06$ & $172,0 \pm 2,1$ & $308,8 \pm 4,0$ & 46 & $42,3 \pm 0,04$ & $158,4 \pm 2,0$ & $274,6 \pm 4,2$ \\
74,5 & $52,6 \pm 0,04$ & $200,7 \pm 2,3$ & $423,4 \pm 3,9$ & 73 & $41,5 \pm 0,08$ & $195,6 \pm 2,3$ & $334,6 \pm 4,1$ \\
91 & $50,6 \pm 0,06$ & $280,1 \pm 2,1$ & $567,0 \pm 4,3$ & 91 & $44,8 \pm 0,09$ & $238,5 \pm 2,6$ & $431,9 \pm 5,1$ \\
119 & $52,8 \pm 0,07$ & $286,6 \pm 0,9$ & $606,2 \pm 2,9$ & 117 & $45,3 \pm 0,07$ & $213,7 \pm 2,5$ & $389,6 \pm 4,9$ \\
167 & $55,4 \pm 0,06$ & $212,0 \pm 2,4$ & $475,3 \pm 4,9$ & 167 & $40,1 \pm 0,07$ & $214,1 \pm 2,6$ & $354,4 \pm 4,2$ \\
\hline
\end{tabular}

Зерно пшеницы сорта Приморская 40 подвергли солодоращению в иных условиях. Проращивание провели при возрастающих температурах от 11 до $15^{\circ} \mathrm{C}$. Оба режима используются для получения пшеничного солода [8]. Результаты представлены в таблице 3.

Накопление амилолитических ферментов происходило по-разному. В случае убывающих температур максимальная величина ДС была достигнута несколько раньше. Полученные данные свидетельствуют о том, что при режиме с убывающими температурами максимальный уровень амилолитических ферментов наблюдается через 4 суток проращивания и достигает $431,9{ }^{\circ} \mathrm{WK}$, а при режиме с возрастающими температурами максимальный уровень амилолитических ферментов приходится на пятые сутки солодоращения, и при этом уровень диастатической силы ниже - 393,3 ${ }^{\circ} \mathrm{WK}$. Это согласуется с литературными данными [8], что солодоращение при убывающих температурах положительно сказывается на диастатической силе пшеничного солода, полученного из европейских сортов пшеницы.

Ранее нами показано [20], что сорта яровой мягкой пшеницы Приморская 39, Приморская 40 в соответствии с классификацией, принятой для солодоращения, относятся ко II категории (с низкой вязкостью сусла и высокой степенью растворения белка), а для такой пшеницы предпочтительно использовать проращивание в режиме с повышенными температурами [21]. Вновь полученные данные согласуются с этим утверждением - проращивание в режиме убывающих температур велось при более высокой температуре и привело к более высокому уровню амилолитических ферментов.

Необходимая стадия получения солода из любых зерновых культур - высушивание. Время проращивания зерна перед высушиванием было различным, в случае режима с убывающими температурами оно составило 91 ч, при режиме с возрастающими температурами - 122 ч. Готовность свежепроросшего солода определяют по длине ростка, он должен составлять 2/3 длины зерна [21]. Так как проращивание в режиме убывающих температур велось при более высокой температуре, время солодоращения было меньше.

Известно, что при высушивании свежепроросшего солода амилолитическая активность уменьшается, главным образом - за счет инактивации термолабильной $\beta$-амилазы [9].

Некоторые характеристики сухого пшеничного солода, полученного при проращивании в режиме убывающих температур, представлены в таблице 4.

Таблица 3. Изменение ДС при разных режимах проращивания сорта Приморская 40

\begin{tabular}{c|c|c|c|c|c|c|c}
\hline \multicolumn{4}{c|}{ С возрастающими температурами } & \multicolumn{3}{c}{ С убывающими температурами } \\
\hline $\begin{array}{c}\text { время от } \\
\text { начала со- } \\
\text { лодо- } \\
\text { ращения }\end{array}$ & $\begin{array}{c}\text { содержание } \\
\text { влаги в } \\
\text { зерне, \% }\end{array}$ & $\begin{array}{c}\text { диаста- } \\
\text { тическая } \\
\text { сила, }{ }^{\circ} \mathrm{WK}\end{array}$ & $\begin{array}{c}\text { ДС, CB, } \\
{ }^{\circ} \mathrm{WK}\end{array}$ & $\begin{array}{c}\text { время от } \\
\text { начала со- } \\
\text { лодо- } \\
\text { ращения }\end{array}$ & $\begin{array}{c}\text { содержание } \\
\text { влаги в } \\
\text { зерне, \% }\end{array}$ & $\begin{array}{c}\text { диаста- } \\
\text { тическая } \\
\text { сила, }{ }^{\circ} \mathrm{WK}\end{array}$ & $\begin{array}{c}\text { ДC, CВ, } \\
{ }^{\circ} \mathrm{WK}\end{array}$ \\
\hline 0 & $10,3 \pm 0,07$ & $49,4 \pm 2,1$ & $55,1 \pm 3,3$ & 0 & $10,3 \pm 0,07$ & $49,4 \pm 2,1$ & $55,1 \pm 3,3$ \\
8,5 & $30,0 \pm 0,05$ & $61,3 \pm 2,5$ & $87,6 \pm 3,6$ & 3 & $26,1 \pm 0,06$ & $82,3 \pm 1,9$ & $111,4 \pm 3,5$ \\
25 & $35,6 \pm 0,05$ & $65,3 \pm 3,0$ & $101,4 \pm 4,6$ & 25 & $38,2 \pm 0,07$ & $147,4 \pm 2,4$ & $238,7 \pm 3,9$ \\
54 & $43,3 \pm 0,08$ & $75,5 \pm 2,5$ & $133,2 \pm 4,4$ & 46 & $42,3 \pm 0,04$ & $158,4 \pm 2,0$ & $274,6 \pm 4,2$ \\
78,5 & $45,8 \pm 0,06$ & $110,1 \pm 2,8$ & $203,0 \pm 5,1$ & 73 & $41,5 \pm 0,08$ & $195,6 \pm 2,3$ & $334,6 \pm 4,1$ \\
101,5 & $47,9 \pm 0,07$ & $194,8 \pm 3,0$ & $373,8 \pm 5,6$ & 91 & $44,8 \pm 0,09$ & $238,5 \pm 2,6$ & $431,9 \pm 5,1$ \\
123,5 & $50,7 \pm 0,06$ & $193,9 \pm 2,7$ & $393,3 \pm 3,8$ & 117 & $45,3 \pm 0,07$ & $213,7 \pm 2,5$ & $389,6 \pm 4,9$ \\
196,5 & $53,3 \pm 0,06$ & $173,4 \pm 2,1$ & $371,3 \pm 4,3$ & 167 & $40,1 \pm 0,07$ & $214,1 \pm 2,6$ & $354,4 \pm 4,2$ \\
\hline
\end{tabular}


Таблица 4. Характеристика сухого солода

\begin{tabular}{l|c|c}
\hline \multicolumn{1}{c|}{ Показатели } & Приморская 39 & Приморская 40 \\
\hline Содержание влаги, \% & $4,8 \pm 0,04$ & $5,6 \pm 0,05$ \\
Экстрактивность & $76,2 \pm 0,6$ & $74,1 \pm 0,8$ \\
Диастатическая сила WK, CB & $427,6 \pm 4,1$ & $324,6 \pm 4,9$ \\
\hline
\end{tabular}

\section{Выводы}

1. Показано, что количество белковых веществ в зерне влияет на накопление амилолитических ферментов во время проращивания зерна. При проращивании пшеницы Приморская 39, Приморская 40 зерно с более низким уровнем белковых веществ показало более высокий уровень амилолитических ферментов.

2. На образование амилолитических ферментов влияет температурный режим при проращивании. Для пшеницы сорта Приморская 40 предпочтительно использовать режим с убывающими температурами.

\section{Список литературы}

1. Демьянов Н.С. Рынок зерновых: текущая ситуация и прогнозы // Экономика сельскохозяйственных и перерабатывающих предприятий. 2011. №4. С. 62-67.

2. Агропромышленный комплекс России в 2011 году: экономический обзор // АПК: экономика, управление. 2012. №3. С. 58-68.

3. Шелленбергер И.А. Производство и использование пшеницы // Пшеница и оценка ее качества. М.,1968. С. $14-24$.

4. Казаков Е.Д. Зерноведение с основами растениеводства. М., 1973. 287 с.

5. Delvaux F., Combes F.J., Delvaux F.R. The effect of wheat malting on the cooloidial haze of white beers // MBAA TQ. 2004. Vol. 41, N1. Pp. 27-32.

6. Depraetere S.A., Delvaux F, Coghe S., Delvaux F.R. Wheat variety and barley malt properties: influence on haze intensity and foam stability of wheat beer // J. Inst. Brew. 2004. Vol. 110, N3. Pp. 200-206.

7. Казаков Е.Д., Карпиленко Г.П. Биохимия зерна и хлебопродуктов. СПб., 2005. 512 с.

8. Нарцисс Л. Технология солодоращения. СПб., 2007. 582 с.

9. Кунце В. Технология солода и пива. СПб., 2009. 1064 с.

10. Jin Y.-H.,. Du J.-H,. Zhang K.-L,. Zhang X.-C. Effects of wheat starch contents on malt qualities // J. Inst. Brew. 2011. Vol. 117, N4. Pp. 534-540.

11. Blazek J., Copeland L. Amylolysis of wheat starches. I. Direstion kinetics of starches with varying functional properties // J. Cereal Sci. 2010. Vol. 51. Pp. 265-270.

12. Bamforth C.W. Current perspectives on the role of enzymes in brewing // J. Cereal Sci. 2009. Vol. 50. Pp. 353-357.

13. Бэмфорт Ч. Новое в пивоварении. СПб., 2007. 520 с.

14. Jin Y., Zhang K.,. Du J. Effects of wheat protein content on endosperm composites and malt quality //J. Inst. Brew. 2008. Vol. 114, N4. Pp. 289-293.

15. Agu R.C., Palmer G.H. Some relationships the protein nitrogen of barley and the production of amylolytic enzymes during malting // J. Inst. Brew. 1998. Vol. 104, N5. Pp. 273-276.

16. Molina-Cano J.-L., Polo J.P., Romagosa I., MacGregor A.W. Malting behavior of barleys Grown in Canada and Spain as related to hordein and Enzyme content // J. Inst. Brew. 2004. Vol. 110, N1. Pp. 34-42.

17. Jin Y., Du J., Zhang K., Xie L., Li P. Relationship between Kolbach index and other quality parameters of wheat malt // J. Inst. Brew. 2012. Vol. 118, N1. Pp. 57-62.

18. Каталог сортов полевых, овощных и плодово-ягодных культур, возделываемых в Приморском крае / под ред. А.К. Чайка. М., 2005. 244 с.

19. Agu R.C. Some relationships Between malted Barleys of Different Nitrogen Levels and the Wort Properties // J. Inst. Brew. 2003. Vol. 109, N2. Pp. 106-109.

20. Ростовская М.Ф., Загария С.Ю., Алябьев Б.А., Клыков А.Г. Пивоваренный солод из сортов пшеницы, возделываемых в Приморском крае // Пиво и напитки. 2009. №4. С. 36-38.

21. Меледина Т.В. Сырье и вспомогательные материалы в пивоварении. СПб., 2003. 304 с. 
Rostovskaya M.F. ${ }^{*}$, Izvekova A.N. ${ }^{1}$, Klikov A.G. ${ }^{2}$ ACCUMULATION OF AMYLOLYTIC ENZYMES IN WHEAT GRAIN DURING MALTING PROCESS

${ }^{1}$ Far Eastern Federal University, School of biomedical, Sukhanova, 8, Vladivostok, 690950 (Russia), e-mail: rost-mf@mail.ru

${ }^{2}$ Primorsky Research Institute of Agriculture, Volozhenina, 30, Timiryazevskiy village, Ussuri region, 692539

(Russia), e-mail:fe.smc_zf@mail.ru

The content of protein, starch, amylolytic enzymes in the grain of the two varieties of spring wheat (Triticum aestivum L.) grown in the Primorye Territory was determined. The accumulation of amylolytic enzymes in the germination process of wheat with different levels of proteins in the grain was investigated. The effect of mode of germination to accumulation amylolytic enzymes in order to optimize the malting process of grain in obtaining wheat malt also was studied.

Keywords: amylolytic enzymes, diastatic power, germination process, malt, protein composition, wheat.

\section{References}

1. Demianov N.S. Ekonomika sel'skokhoziaistvennykh i pererabatyvaiushchikh predpriiatii, 2011, no. 4, pp. 62-67. (in Russ.).

2. APK: ekonomika, upravlenie. [Agriculture: economics, management]. 2012, no. 3, pp. 58-68. (in Russ.).

3. Shellenberger I.A. Pshenitsa i otsenka ee kachestva. [Wheat and quality assessment]. Moscow, 1968, pp. 14-24. (in Russ.).

4. Kazakov E.D. Zernovedenie s osnovami rastenievodstva. [Zernovedenie the basics of crop production]. Moscow, 1973, 287 p. (in Russ.).

5. Delvaux F., Combes F.J., Delvaux F.R. MBAA TQ, 2004, vol. 41, no. 1, pp. 27-32.

6. Depraetere S.A., Delvaux F, Coghe S., Delvaux F.R. J. Inst. Brew., 2004, vol. 110, no. 3, pp. 200-206.

7. Kazakov E.D., Karpilenko G.P. Biokhimiia zerna i khleboproduktov. [Biochemistry of grain and grain products]. St. Petersburg, 2005, 512 p. (in Russ.).

8. Nartsiss L. Tekhnologiia solodorashcheniia. [Malting technology]. St. Petersburg, 2007, 582 p. (in Russ.).

9. Kuntse V. Tekhnologiia soloda i piva. [Technology malt and beer]. St. Petersburg, 2009, 1064 p. (in Russ.).

10. Jin Y.-H.,. Du J.-H,. Zhang K.-L,. Zhang X.-C. J. Inst. Brew., 2011, vol. 117, no. 4, pp. 534-540.

11. Blazek J., Copeland L. Amylolysis of wheat starches. I. J. Cereal Sci., 2010, vol. 51, pp. 265-270.

12. Bamforth C.W. J. Cereal Sci., 2009, vol. 50, pp. 353-357.

13. Bemfort Ch. Novoe v pivovarenii. [New in brewing]. St. Petersburg, 2007, 520 p. (in Russ.).

14. Jin Y., Zhang K.,. Du J. J. Inst. Brew., 2008, vol. 114, no. 4, pp. 289-293.

15. Agu R.C., Palmer G.H. J. Inst. Brew., 1998, vol. 104, no. 5, pp. 273-276.

16. Molina-Cano J.-L., Polo J.P., Romagosa I., MacGregor A.W. J. Inst. Brew., 2004, vol. 110, no. 1, pp. $34-42$.

17. Jin Y., Du J., Zhang K., Xie L., Li P. J. Inst. Brew., 2012, vol. 118, no. 1, pp. 57-62.

18. Katalog sortov polevykh, ovoshchnykh i plodovo-iagodnykh kul'tur, vozdelyvaemykh v Primorskom krae. [Catalogue of Varieties of field, vegetable and fruit crops cultivated in the Primorye Territory]. Ed. A.K. Chaika. Moscow, 2005, 244 p. (in Russ.).

19. Agu R.C. J. Inst. Brew., 2003, vol. 109, no. 2, pp. 106-109.

20. Rostovskaia M.F., Zagariia S.Iu., Aliab'ev B.A., Klykov A.G. Pivo i napitki, 2009, no. 4, pp. 36-38. (in Russ.).

21. Meledina T.V. Syr'e i vspomogatel'nye materialy v pivovarenii. [Raw and auxiliary materials in brewing]. St. Petersburg, 2003, 304 p. (in Russ.).

\footnotetext{
* Corresponding author.
} 